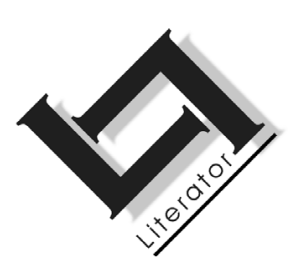

\title{
Politics in poetry: epic poetry as a critique of Dutch culture
}

\author{
O.M. Heynders \\ Department of Humanities \\ Tilburg University \\ NETHERLANDS \\ E-mail: O.M.Heynders@uvt.nl
}

\begin{abstract}
This article describes a Dutch volume of epic poetry, using a disciplinary strategy (concepts and devices from narrative studies) and a cultural analytical and rhetorical approach. The volume "Roeshoofd hemelt" by Joost Zwagerman (2005) is a political poetic text that raises fundamental questions on issues of mental illness and on consumerism in contemporary Dutch society.
\end{abstract}

\section{Opsomming}

Politiek in die poësie: epiese poësie as kritiek op die Nederlandse kultuur

Hierdie artikel beskryf die epiese poësie in 'n Nederlandse digbundel deur gebruik te maak van 'n dissiplinêre teoretiese strategie (konsepte en tegnieke uit die verhaalteorie) en 'n kulturele analitiese en retoriese benadering. Die bundel "Roesthoofd hemelt" van Joost Zwagerman (2005) is 'n politieke teks wat fundamentele vrae vra oor die problemtiek van geestesgesondheid en die verbruikerskultuur in die kontemporêre Nederlandse gemeenskap.

\section{Introduction}

In Murder in Amsterdam: the death of Theo van Gogh and the limits of tolerance, Buruma (2006:96) depicts his native country as the "land of guilty memories", a society in which tolerance is exhausted. The essay is a reconstruction of what happened on the morning of 2 November 2004, when filmmaker Theo van Gogh was murdered in the streets of Amsterdam by a young fundamentalist Moroccan 
student. Buruma tries to find out what the atmosphere in Holland was like at the time, how politicians reacted, and why Van Gogh on his bike was the prime target. One could say that on a first level the essay can be interpreted as a journalistic discourse, offering information on Dutch multicultural society. On another level, however, Buruma describes Van Gogh's background, and links this to his own education in the sixties in the prosperous bourgeois city, The Hague, where tolerance was the magic word. We can read this as the sociological perspective. One might emphasise how Buruma takes on the role of a historian of mentality in connecting the unpleasant discussion on the limits of multicultural society and the position of immigrants from Muslim background 1 to the traumas of World War II, in which many immigrant Jews were deported and the rest of the Dutch population stood by and let it happen. Indifference proves to be the other side of tolerance. Developing the line of argumentation from there, Buruma discusses from a philosophical point of view the shifts in right- and left-wing thinking, and points out that tolerance, freedom of speech and the ideal of equality got blurred in a discourse on the negotiation of values. The outcome of this was that many prominent Dutch intellectuals have come to consider Islam as a threat to the values of the Enlightenment.

One of the most confronting observations Buruma makes from the critical perspective of a relative outsider, is that irony is an essential part of the Dutch make-up. Filmmaker Van Gogh was a champion of irony. However, he also misused it, as Buruma (2006:112) makes clear:

[Irony] is indeed part of the tradition, and a great deal of humor depends on it. But there is a less positive side to this tradition. Irony can be a healthy antidote to dogmatism, but also an escape from any blame. (...) Irony is a great license for irresponsibility. Theo van Gogh liked to call himself the village idiot, as though that absolved him of everything. And yet he wanted to be taken seriously too. This wanting it both ways is a common disease in Dutch intellectual discourse[.]

This is a very sharp analysis of the typical Dutch feature of ironisation in debates, something that in the end is based on the ideal of the freedom of expression. To Buruma it is clear that irony is often rude and hurting or even devastating. In a speech delivered in Mel-

1 This discussion was dominated by the blunt statements of populist politicians such as Geert Wilders and Rita Verdonk. See also Scheffer (2008). 
bourne, in August 2009, he stresses the importance of realising what is said to whom under what circumstances. Something that can be said by one minority, is not accepted from others; something that can be expressed by an artist, a filmmaker, ironically trying to push the limits of what is permissible, will not be accepted from a journalist or an academic.

Political discourse in society is a complicated, many-leveled research object. It is, therefore, something that has to be discussed from various disciplinary perspectives. In this article, I will start from poetry and investigate how a significant contemporary Dutch writer presents a critical image of Dutch society in an epic poem. Joost Zwagerman, who after the death of Theo van Gogh decided that there was no longer any point in writing fictional novels, and became an important newspaper essayist and columnist in the years after 2004,2 was involved in the tragedy himself. Van Gogh's film Submission, based on a scenario written by former Somali immigrant and then politician Ayaan Hirsi Ali, considered deliberately insulting and embarrassing many Islamic people, was first shown in a highbrow cultural programme on Dutch TV, in which Zwagerman was the host interviewer.

I will use these introductory remarks as the backdrop to an argument that runs as follows. Tolerance in Dutch society has been declining since the end of the 1990s. While the state, or more precisely politicians such as former Prime Minister Jan Peter Balkenende (Christian Democrat) focus on norms and values, the everyday micropractice in society is becoming more harsh, rude and even xenophobic. Dutch citizens suffer from overconfidence, greed, fear and suspicion. This reality is discussed by current (mostly female) literary writers and public intellectuals, such as Marja Pruis (Casino, 2004), Désanne van Brederode (The awakening, 2004), Marjolijn Februari (De literaire kring, 2007), and Louise O. Fresco (The utopists, 2007), who reflect on political developments and criticise Dutch society in their works. ${ }^{3}$ In this article I will discuss a poetic epic text, "Roeshoofd hemelt" (Flushhead heavening, 2005) and examine the ideas and narrative procedures by means of which in these poems the societal critique is put into effect.

2 The first fictional text he wrote after 2004 is the short novel, Duel (2010).

$3 \quad$ See Heynders (2008:159-172) for an article on these women writers. 


\section{The volume Roeshoofd hemelt}

In the opening lines of this, his fourth volume of poetry, Zwagerman seduces the reader to enter a department store in which one can buy literally anything: huge relics and trade boxes, IKEA-cabinets and planet sex, a ladies' glove from the year 1803 and pornsignalling rollators. A little under a hundred pages later, we are thrown out of the supermarket with the same cheery meaningless rhetoric that invited us in:

Bij T-Mart ontvangt $u$

zestig melkwegpunten als $u$

schappend stukjes buitenwacht

in uw singelasingelawinkelwagen deponeert.

At T-Mart you get

sixty Galaxy Bonus Points

for de-shelving bits of outside world

into your jolly, jolly-happy-soul trolly. 4

The journey into the market results in a story of a man suffering from madness, depersonalisation and delusion. At the same time it is a story about the doom and failure of commercialism, while the one thing that is not for sale at T-Mart, is a new life. The volume offers a critique of Dutch society, but also addresses questions of epic and narrative form. Zwagerman uses the registers of postmodernism, referring to elements of high and low culture and introducing various voices in the poems. The poems are ideological, in so far as they present "a body of norms and ideas that appear natural as a result of their continuous and mostly tacit promotion by the dominant forces in society" (Hermans \& Vervaeck, 2007:217). Ideology is a more or less coherent system of norms and ideas, which most of the time are not made explicit. Starting from a close reading, I will analyse the various narrative devices and pick out ideological statements in this volume and in doing so I will automatically move from inside the text to society outside, from poetry to politics.

Roeshoofd hemelt consists of 62 poems divided more or less equally over three "departments": "Adem", "In en", and "Uit" ("Breathe", "In and", and "Out"). Some of the poems in these three parts are written in free verse and printed in a specific typeface (DTL-Haarlemmer), others are classical rhyming verses and sonnets printed in Helvetica

4 Translations of the poems are done by H.W.A Verhulst, School of Humanities, Tilburg University. 
font. The poems in DTL-Haarlemmer-type are told from another narrative perspective than those in Helvetica; in the former poems, the narrator is heterodiegetic, observing things from a distance; in the latter the focaliser is the protagonist. The poems in the volume belong together and tell the story of a mentally unstable character who is sectioned to a clinic because of a manic episode.

The story is based on a manipulative type of narration, which could be characterised with a reference to Genette as variable focalisation. Variable focalisation implies that there is more than one reflector (Jahn, 2007:98). A good example of variable focalisation can be found in Virginia Woolf's Mrs Dalloway (1925): events are seen through the eyes of Clarissa Dalloway, Peter Walsh, Septimus Warren Smith and others. At first sight, the story in these poems seems also to be presented by different characters, third-person and firstperson narrators. However, it could well be that these narrators all merely exist in the head of protagonist roeshoofd (hence the name flushhead). His psychotic, unbalanced mind is host to many others. In the beginning of the story, there is no way of dissecting this complexity. It could be that there is only one focal position, a heterodiegetic narrator, who does not participate in the circumstances about which he tells the story, and who describes what is happening to flushhead. I quote from the second poem:

roeshoofd komt aan op een zomerdag de inrichtingstuin is zonbestoven schuin voor de ingang wappert een vlag het gebouw zindert warm als een oven

roeshoofd groet het ontvangstcomité het welkom is bijna majestueus verplegers vormen een assemblee patiënten gedragen zich genereus

flushhead arrives on a summer's day the clinic's garden's sun ray-pollinated in front of the entrance a flag is fluttering the building's shimmering warm as an oven

flushhead greets the welcoming committee a welcome almost majestic nurses forming an assembly patients behaving generously

The story begins in medias res. The protagonist of the story arrives at the clinic after a suicide attempt. Roeshoofd is the name of this 
character, not written with a capital letter as though it is not important enough to be written as an official name or because it is meant to be generic. However, in other poems he is called "vastklant R." (regular customer R.; poem 13), "meneer R." (Mister R.; poem 14) or simply "R." (poem 21). The different names indicate that this character is experiencing himself as being the centre of an internal universe filled with different voices addressing him.

R. steals a bi-polar disorder in the supermarket, he is found guilty and sent to an asylum. At the end, in poems 60 and 61, he has died and then realises that he was never really alive: "je bent nooit anders dan dood geweest" (you've never been anything but dead; poem 101). The story of the manic-depressive illness is bizarre and pathetic. Because of the multiple focalisation the reader has no way of telling whether what is described is happening in reality or is taking place in R/roeshoofd's mind. All his fears, dreams, hallucinations and fantasies could be real. When $R$. is finally taken out of the clinic in a coffin, he doesn't know that he is dead. In the last poem, his parents endeavor to buy their son at T-Mart, the place where everything is for sale. Unfortunately, this product is one that is not available.

The 62 epic poems challenge a narrative-focused interpretative strategy. They function as narrative units chained together. The reader immediately realises that the poems tell a strange but coherent story. One of the characteristics of a narrative structure is the sequential temporality: parts follow other parts in time. Anachrony (non-chronological narration) and analepsis (flashbacks) underline the unreliability of the narration. The story develops from the arrival at the clinic (part 1, poem 2) to the theft of a bi-polar disorder in the supermarket (part 1, poem 12), which could be considered as a period of mania or psychosis; then to being institutionalised (part 2, poem 24) in a clinic (most poems of part 2); to the phone calls with the lawyer (part 3, poem 48) and the trial in court (poem 50) and finally to the treatment (poem 51) and to death (poems 60 and 61). There are some gaps and omissions in the story; we do not know what $\mathrm{R}$. did before his breakdown, or what his previous life looked like.

In the beginning of the story, the reader is confronted with a fictional perspective. The supermarket offers products that are not available in the real world. However, figures in the market are modeled after persons and activities from the real world and these are far from random choices: Niels Bohr (the father of quantum mechanics) is laughing with his comrades, Lao Tse (Chinese sage and founder of 
Taoism) wants to be picked up from the children's paradise, Hermes Trismegistus (associated with Egyptian god of wisdom Toth) gets a slice of meat, Atilla (quintessential cruel male hero) collects Pokemon cards (Japanese game cards). The supermarket is a fantasy world in which imaginary persons, in some way or another related to the mystical or magical, are having fun and doing their shopping. In the second part of the story, the camera switches from T-Mart to the clinic. In poem 24, "In hechtenis" ("In custody") the narrator verbalises the story of $\mathrm{R}$. in internment. It is the narrator who decides what is told; R. no longer seems to be the director of his own life:

Hoe moet R. zichzelf noemen?

Waar bevindt hij zich nu hij gevat

is ingestraald en uitgezonden?

Niet zoveel doen aan balalaikavragen,

smoest naast hem een dundito bajesklant,

het koopziek gezicht verdacht ongeschonden.

Broeder Vastklant! Je bent in de catacomben

van je eigen koopwaar aanbeland. (Zwagerman, 2005:42.)

What is $R$. to call himself?

Where is he now caught

irradiated and emitted?

Don't bother with balalaika questions

a dundito jailbird whispers next to him,

the shopping-crazed face suspiciously intact.

Brother Regular! You have landed in the catacombs

of your own merchandise.

In the following poems (25-36) the perspective of narration shifts again to roeshoofd, as internal focalisation, but roeshoofd's is not a reliable perspective, he loses his grip on the world, he fantasises about possible ways of committing suicide, drinking chloride, strangling another patient. In the third part of the story, roeshoofd is defended by a popular lawyer who expresses himself in absurd and funny language. In the end, the discrepancies between the mind and the body become so strong that they cause the system to collapse: the body dies while roeshoofd's mind still continues to be aware. His parents try to buy him back at T-Mart. The story of roeshoofd is becoming more and more exasperating, while the reader has to accept that there is no way out of this smothered mind.

When a poet wants to tell a story, there are three options open to him. He can write a rather long epic poem, a novel in verses or a narrative-based volume of poetry. In Dutch literature examples of the first category would be Mei (1889) and Pan (1912) by romantic 
poet Herman Gorter, or Awater (1934) and Het uur $U$ (1937) by modernist poet Martinus Nijhoff, and more recently, Goede manieren (1989) by postmodern poet Robert Anker. These episodic poems tell the story of a protagonist searching for something lost. The second category, the novel in verses, is worked out by Pieter Boskma in De aardse komedie (2002). This is a soap opera, built on a structure of rhyming lines. The third category involves volumes of narrative, often autobiographical poetry, for instance De vrouw in het woud (1912) by Henriëtte Roland Holst or Dochter (1984) by Eva Gerlach. Roeshoofd hemelt fits in both the first and the third categories.

In The interplay of narrative and lyric: competition, cooperation, and the case of the anticipatory amalgam, American scholar Dubrow (2006:268) presents an overview of various text forms in between prose and poetry and maintains that a combination of the two genres results in an amalgam of mental and physical space, of present and past events:

Risking the dangers of schematization, one could say that if narrative often ... involves a story that is set in the past (which differs of course from the time of discourse) and located in a mimesis of physical space ('it happened in this place') and lyric often the mode that focuses on the lyric present or overlapping time schemes and a mimesis of mental space ('it is happening in my mind'), the hybrids in question are typically optatives located both in the mind in the present and in a physical space that may exist in the future.

The intermingling of narrative and poetry results in a strange, flimsy space. This is exactly what we find in Zwagerman's poetry. The beginning and the ending of roeshoofd's story are fluid, the reader is closed in by the fantasies and fears of the psychiatric patient, closed in by his words and the limitless language of his manic periods.

\section{Close reading of a narrative poem}

For a further analysis of the narrative devices of the volume, let us examine one poem: the three-pages long free verse, entitled "Door een wonder" ("By a miracle"), printed in DTL-Haarlemmer typeface, in which a classical, rhyming sonnet (printed in Helvetica typeface) is embedded as a kind of intermezzo. This is the seventeenth poem of the first part of the volume. The poem describes roeshoofd experiencing a manic period. 
1. lemand in een wassend filial

2. smeedt complotjes

3. van slierten muziek.

4. lemand aan de entreepoort

5. draait tjokvol hartslag

6. nieuwe stoppen in

7. lemand kuiert langs een voorlopige zon.

8 Als doodswens nu eens niets dan woord is

9. waar spellingscontrollers in ritsel mee praten.

10. Als vastklant $R$. nu eens niets dan

11. woorden heeft gezocht.

Someone in a waxing branch

is hatching conspiracies

of wisps of music.

Someone at the entrance gate chockful of heartbeat

is screwing in new fuses.

Someone is strolling past a preliminary sun.

What if death-wish is no more than word

engaged in rustling conversation by spelling checkers

What if customer $R$. has been

looking for nothing but words.

Two structuring lyrical elements are functional: the repetition of words and the white spaces between the lines. "lemand" (Someone") is acting. Someone is an accidental, non-specific character. Someone is usually passed by when one is doing the shopping in a supermarket, registering the products and planning what to buy. He is faceless, without identity. In the third line, there is a reference to the boring music we can hear in supermarkets everywhere in western societies. Music meant to stimulate the shopping, creating an atmosphere of friendliness, comfort and familiarity. The second stanza shows the entrance of the market, but we do not know what exactly the "someone" is doing there: he "draait tjokvol hartslag nieuwe stoppen in" ("chock-full of heartbeat he's screwing in new fuses"). Could this be a description of roeshoofd, entering the market full of energy? Stanza three, just a single line, refers to the slow walking one does in a supermarket, observing the products, not yet deciding what to purchase. The "voorlopige zon" ("preliminary sun") 
could refer to a light, putting the market in a pleasant gleam. Just like the music, this light is meant to add to the pleasure of buying.

The first few stanzas depict a supermarket, recognisable to every Westerner. Consumerism gives rise to contemporary rituals. According to French philosopher Baudrillard (2007:159), the

... consumer society is not simply characterized by the abundance of goods and services but by the more important fact that in this society everything is a service. What is available to be consumed never presents itself as pure and simple product, but as a personal service, as gratification.

This rhetoric of service is typical of T-Mart, as it is of practically all the supermarkets in the western world.

In stanza four, we notice the heterodiegetic narrator, commenting on the action of protagonist R., "Als doodswens nu eens niets dan woord is." ("What if death wish is no more than word?") After all, there are so many words in advertising which are merely suggestive of moods and feelings, rather than being truly referential. The narrator doesn't seem to take the character's suicidal inclinations very seriously. However, from previous poems, the reader already knows that R. has tried to hang himself in his home, that he has kept on dreaming of various ways of committing suicide, using the electric chair, drowning himself in the sea or throwing himself in front of a fast-moving train, drinking arsenic and chloride, opening the gas tap.

The chronological sequence of events is mixed up here as it may well be in R's mind. R. entered the clinic as early as the second poem of the volume; here in poem 17 we are confronted with events that happened before his admission to the clinic. Sequences are disaligned and the perspective of the narrator is not fixed, as a result of which there is no clear center of consciousness. The text offers a typical example of what Heather Dubrow discussed; lyrical and narrative statements are interwoven, time and space are getting fluid. Let's read the next part of the poem.

12. Vanaf hoogmuur en plafond

13. dansten camera's wuft en duchtig in de heupen,

14. volgden R.'s losse doen en laten.

15. Hij had stoornis bipolair 5 in serie

5 bipolar $=$ manic depressive. 
16. zacht uitgepakt, verwachtte donder en grom,

17. kromde bij voorbaat zijn glimlichte rug.

18. Maar niets dan sloomte van

19. slingers gedachten welde grijs

20. vanuit de verpakking op:

21. moet je nog verder mijn joch,

22. heeft buiten de zon die blauwkazend smelt

23. jouw komende diefstal in de gaten?

24. Zijn woorden altijd als steen

25. en kan ik straks schuilen

26. in dingen die ik nooit

27. heb gedacht of gedaan?

From highwall and ceiling cameras were dancing frivolous and formidable in the hips were following R's every odd move.

Disorder bipolar in sequence he had softly unwrapped, expecting thunder and grumbling arching his glim-lit back in anticipation.

But nothing but sluggish garlands of thought welled up grey out of the wrapping: You've got any further to go, my boy?, the sun outside melting like blue cheese is it on to you and your imminent theft?

Are words always like stone and will I be able to take shelter later in things I never thought or did?

In lines 12-15, we follow $R$. in the market, just like the cameras that are observing him. Then R. gently unwraps the disorder and prepares himself for the accusation of theft by the shop manager. But no one seems to notice his action. All that happens is that the disorder, as a voice inside R.'s head, is asking, "moet je nog verder mijn joch" ("You've got any further to go, my boy?") Hearing voices inside one's head is a typical phenomenon in people suffering from mental disorder. It feels as if someone else is controlling one's thoughts and one's life. Dissociation and fear are the result. In lines $24-27, R$. reacts to the words and voices in his head, "kan ik straks schuilen in dingen die ik nooit heb gedacht of gedaan?" ("Will I be able to take shelter later in things I never thought or did?") And again, it is not clear who is speaking to whom here. R. is the focaliser, the center of consciousness, but since his mind is scrambled, we are losing a clear perspective on what exactly is happening.

28. R. blikt in winkelwagentje.

29. Spullen zijn er als regen in gevallen. 
30. Psychose. Depressie. Met barcode en folie.

31. R. dempt zich in kassarij.

32. Ziet: in een mens huist

33. achter zielsmuur diezelfde mens

34. die zichzelf in stille perfectie

35. aan andermans ogen onttrekt.

36. Robuust stijgt stilmens op in vastklant $R$.

37. en voelt dankzij ontseald product

38. al het witte en ware dat voordien

39. door craquelé van zijn

40. buitenste zelf bleef bedekt.

$R$. glances into supermarket trolly

Stuff fallen in there like rain

Psychosis. Depression. With bar code and foil.

$R$. muffles himself in check-out queue.

Behold: in man behind

soul's wall dwells that very same man

who in quiet perfection

eludes another man's eyes.

Robustly quiet-man wells up in regular customer $R$.

and thanks to unsealed product feels

all the white and true that until then

remained covered by the craquelure

of his outward self.

Again the narrative perspective is dynamic. In lines 28-31 we observe R.'s activities from a distance, in lines 32-40 we are drawn into his particular fantasies. He is experiencing a "stilmens" ("quiet man") rising up in his own body. Then he realises the "witte en ware" ("white and true") being in himself. This is an experience of being split, the inside and outside of his subjective self are falling apart. Roeshoofd is disintegrating, as people are when suffering from bipolar disorder, also known as manic-depressive illness. This is a brain disorder that causes unusual shifts in mood, energy, and activity levels. In a period of mania people feel high or overly happy and have an unrealistic believe in their abilities. In periods of depression, however, they feel empty and worried and has problems in concentrating and making decisions. Thoughts of death or suicide often come up during these down periods. 6

6 See bipolar disorder at the website of the National Institute of Mental health, USA: www.nimh.nih.gov/../bipolar-disorder/ 


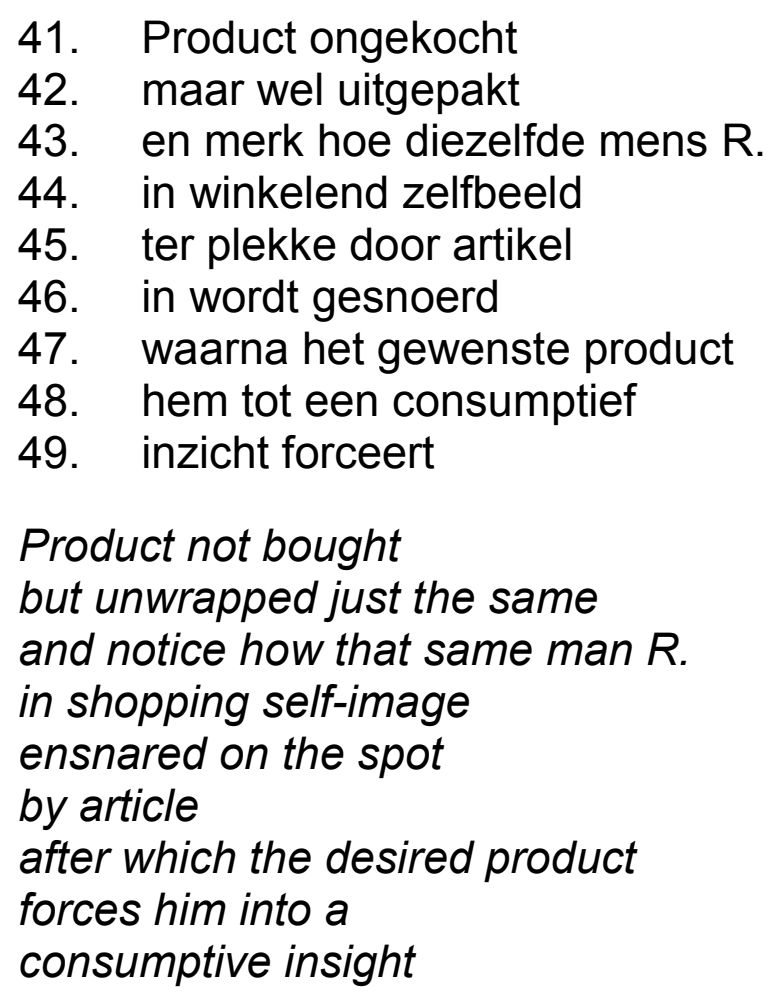

And then the real trouble begins. R. does not pay for the goods he has in his trolley, but undergoes the product taking him in. It seems that $R$. does not feel personally responsible for his actions. And the fact is that he is not accountable. Then he has this sudden moment of insight of "consumptive knowledge". What this involves is printed in another typeface, in a sort of embedded poem. An over-indulgent, messianic sonnet is what follows:

50. soms zegt men duizend doden te sterven

51. een uitdrukking die mijn last ondermijnt

52. in mij voel ik miljarden bederven

53. tot de mensheid met een daver verdwijnt

54. het is onweerlegbaar de zwaarste straf

55. als je tel voor tel alles dood voelt gaan

56. een laatste bloem welkt op het massagraf

57. waaruit zelfs geen schim ooit nog op zal staan

58. ik ben de verabsoluteerde faust

59. geen pact met de duivel kan vermijden

60. dat met mij een finale holocaust

61. zwaar aanzwelt tot het einde der tijden

62. mijn zaad heeft de planeten zwartgesausd

63. welke oerknal beëindigt mijn lijden

sometimes people claim to die a thousand deaths

an expression that undermines my burden 
inside me I feel billions decomposing until mankind disappears with a thunder

the harshest punishment irrefutably is to count by count feel everything dying a last flower fading on the mass grave from which not even a shadow will ever rise again

I am faust made absolute

no pact with the devil can prevent

a final holocaust swelling

heavily with me till the end of time my seed has black-plastered the planets

what big bang will put an end to my suffering?

Melodramatic though it may sound, the sonnet does reflect the feeling of deep despair experienced during the blackest part of the bipolar cycle, which frequently occurs right before full-blown mania sets in. The fourteen lines of this embedded sonnet are rhythmic because of the ten syllables on which each line is built. The rhythm underlines roeshoofd's psychosis: it feels like a pounding in his brain. He envisions being Faust engaged in devilish practices: people dying, millions starving, mankind disappearing, mass graves, final holocaust, black planets. These are pictures and words from a romantic register, referring to blackness and emptiness, and reminding us of the Dutch romantic poet Slauerhoff (his poem "O Engeitado"). After the sonnet, a neutral narrator, which could still be R, commenting on himself and on what is happening, takes over. He now lives through the mania of the bi-polar disorder which was preceded by deep depression.

64. Alles werkt! En dat zonder instructie,

65. uitvouwblad of batterijen. Geen grauwe voile,

66. geen sluier van zwart. Verblindend

67. licht op het alom nabije, vroegere

68. aanschijn vals aangemeerd.

69. Een sneeuwwitte röntgen

70. toont hem de waarheid,

71. het lichaam de dingen

72. tot een en hetzelfde

73. karkas ingekeerd.

Everything's working! Without instructions, fold-out page or batteries. No grey voile, no veil of black. Blinding light on the omnipresent near, former 
appearance falsely moored.

A snowwhite röntgen

shows him the truth,

the body the things

re-entered into

one and the same carcass.

The working of the disorder is like the functioning of a machine. During a depressive episode everything is coloured in black, pictures of doom and feelings of unhappiness are overriding. During a manic episode, the body works like an engine in overdrive, the entire metabolism is speeded up and there is a heightened sense of awareness. All one's senses are sharpened and one feels like one is on top of the world. The image is clear, the light is sharp. A röntgen picture shows the truth. The truth of the empty body with only bones and structures. A body from which the mind is disconnected. And then it is time for a conclusion:

74. T-Mart is blijvend onttroond,

75. dezelfde mens $R$. heeft scherp voor ogen

76. bedrog dat sinds kind pijn doet aan riffen,

77. zoals het door moeders en

78. dichters sinds juttemis uit wordt gelegd.

79. R. kent nu van materie

80. de morsdode massa.

81. Als door een wonder

82. beweegt het karkas

83. en rekent haast niets

84. uit superkar af

85. bij zoiets futiels als

86. een glansrijke kassa.

T-Mart has forever lost its charm

the same man $R$. sees clearly in front of his eyes

deceit that's hurt reefs since kid,

as explained by mothers and poets

ever since hell froze over.

$R$. now knows of matter

the stone dead mass

as by a miracle

the carcass moves

and hardly pays for anything

out of supermarket trolly

at something so insignificant

as a shining check-out 
The euphoria has passed away. The body feels dead. The shoplifting is connected to the dismantling of the ideal of consumerism, "TMart is blijvend onttroond" ("T-mart has forever lost its charm"). Roeshoofd is no more than a carcass, his mania has disappeared. His story is the age-old tragedy of the failure of the individual human being. A miracle gave him the temporary experience of power, but in the end the only thing alive is the body. The only thing left to him is to act without thinking, to behave like a zombie.

\section{Framing the poetic story and the ethos of the epic voice}

Narrative is a mode, not a genre. It is alive and active as a cultural force, not just as a kind of literature. It constitutes a major reservoir of the cultural baggage that enables us to make meaning out of a chaotic world and the incomprehensible events taking place in it. (Bal, 2002:10.)

These words by Bal in the introduction of Travelling concepts of the humanities, point out precisely why epic poetry today should not be considered as an aesthetic genre as such, but might be connected to a cultural practice that is much broader than literature alone. Even this story of a man suffering from a mental disorder, has a wider impact and constitutes a critical reaction to various societal issues. Let me elaborate on this by focusing on the concepts of framing and poetic voice.

The practice of cultural analysis implies that every text has to be placed in a context. The theme of bi-polar illness is situated in a location (the T-Mart, Dutch society, the western world) in which consumerism is dominant. Life in the consumerist environment has become both manic (going on too fast) and depressive (made up by emptiness and fear). In comprehending this connection I will underline and interpret some explicit cultural motives. I will use the concept of framing to clarify the performative dimension of the text.

We can frame the poetic text, make a construction around it through which various ideas can light up. As I pointed out before, French philosopher Baudrillard explained in The consumer society, myths \& structures (2007) how the idea of service and servility is crucial in western societies. Objects no longer serve a purpose; they first and foremost serve you (Baudrillard, 2007:159). One of the myths of the consumer society is the issue of personalisation. We are all cutting ourselves a path through the personalised jungle of optional merchandise, desperately seeking the difference which will make us 
ourselves (Baudrillard, 2007:87). The rhetoric of Zwagerman's TMart is based on the idea that everything is for sale. If you are someone, then you will know what to buy; that is the logic of current supermarket advertisements. It is, however, precisely in this overpersonalisation that the protagonist gets lost, and becomes an "anybody" without subjectivity. I quote from Baudrillard (2007:88):

This 'over-reflexive' expression (personalizing oneself ... in person etc.!) tells the real story. What all this rhetoric says, while floundering about unable to say it, is precisely that there is no one there - no person. The 'person' as absolute value, with its indestructible features and specific force, forged by the whole of Western tradition as the organizing myth of the Subject - the person with its passions, its will, its character (or banality) - is absent, dead, swept out of our functional universe.

Personalisation and de-personalisation is one of the basic themes in Zwagerman's poetic narrative. The protagonist is losing himself in TMart, metaphor of the consumerist society, of a western world focused on material goods. What outlives in this world are empty monologues, advertisers' litanies, a dysfunctional legal structure and a non-caring health system. The consumer has a legitimate, inalienable right to abundance, technology, progress, and growth. However, the real world keeps moving further and further away from him. In the end, even death is not something that is really experienced.

The merry T-mart rhetoric can be connected to what Baudrillard (2007:31) describes as the "miraculous status of consumption": the consumer miracle sets in place a whole array of sham objects, of characteristic signs of happiness. Consumption is governed by a form of magical thinking. In everyday practice, the blessings of consumption are not the outcome of serious or meticulous (hand)work, they are experienced as a miracle. $\mathrm{R}$. is losing his grip on the real world, not only because he is a mentally unbalanced figure, but because of his representativeness of the consumerist man in a western society. Relations of interest, investment or responsibility towards the real world no longer exist. There is no way for the modern citizen to escape from the enforced happiness and enjoyment, which is the equivalent in the new ethics of the traditional imperative to labour and produce. The modern consumer is haunted by the fear of missing out on something. To quote Baudrillard (2007:80) again: "You never know whether a particular encounter, a particular experience (Christmas in the Canaries, eel in whiskey, the Prado, LSD, Japanese-style love-making) will not elicit some 'sensation'." It 
is the fun-morality, the imperative to enjoy oneself that is sanctified in the consumer society.

By framing Zwagermans poems in the text of Baudrillard, we can highlight some of the themes and meanings of this epic story. We open the narrative to a reading in which the poetic text acquires a more communicative quality. It functions as a critique of our society and transposes the story of a psychotic man to everyday life in the West.

Framing the epic poem can highlight a distinctive ideological statement. And from there we can submit two related questions, namely what is the ethical dimension of this epic and what is the position of the implied author or more precisely of the poetic voice? From a rhetorical perspective a narrative is not just a representation of events (the story of a psychotic figure), but also an event in itself, a purposive communicative act (Phelan, 2007:203). My contention is that Zwagerman by writing an epic poem deliberately used a poetic voice to criticise society. In other words, the epic form was ideally suitable for presenting an effective ethical account without losing a certain intellectual distance.

The rhetorical approach suggests that readers make three main types of judgements, namely interpretive, ethical and aesthetic (Phelan, 2007:211). Interpretive judgments concern the structure and the actions of the narrative (we have made them in our close-reading paragraph). Ethical judgments concern the motives and actions of the character and the values implicit in the narrative. Aesthetic judgments are judgements concerning the artistic quality. The ethical judgment emphasises the character roeshoofd as a victim of his illness, but can also point out that he is a victim of the pressures in the demanding globalised consumer society. In fact, other characters such as the attorney (poems "Achter tralies" ("Behind bars") and "Voor de rechter" ("In court")) or the supermarket employee ("Aan het woord" ("Speaking")) or the parents ("Onder ouders" ("Among parents")), are also victims of a society in which language and reality no longer match. They are all using over-confident cliché-type language and standard (as opposed to original) speech. They are all victims of what might be called the McDonaldisation of western society. The authenticity of speech no longer exists. Even language is a sales product.

The ethos of the poetic voice makes it clear that contemporary society is an environment in which authenticity and subjectivity are becoming dilapidated. Illness is considered a metaphor and not some- 
thing that is real and that can be treated. Doctors do not give roeshoofd the right treatment, because of their lack of interest in him. Roeshoofd loses himself in the ongoing stream of words in his heads, words that are not connected to the real world anymore. Words by which he cannot communicate. In modern society, real communication is the problem. Disease is mystified, patients are becoming objects of practices of decontamination. Illness as metaphor, as Sontag has described in her fascinating essay, shows our shallow attitude towards death, our anxieties towards feeling and our inability "to construct an advanced industrial society which properly regulates consumption" (Sontag, 2002:87).

\section{Discussion}

The tolerance that used to be an icon of Dutch society has been declining since the 1990s, the decade in which consumerism had reached its maximum height. Immigration and multiculturalism turned into problems instead of opportunities. The freedom of speech got blurred in ironical and indifferent communication. Moderateness and satisfaction made room for hysteria and Angst. The "pampered society" Buruma remembered from his youth, had changed when he came back in November 2004. Buruma finds an explanation in globalisation:

The Netherlands never was a utopia, but the world had indeed changed since 9/11, and that world had caught up with Amsterdam, just as it had with New York, Bali, Madrid, and London. The Moluccan problem [passengers held hostage in a hijacked train and children held hostage at a school in 1977, O.H.] was a local tragedy. But Mohammed Bouyeri, a sad loner from an Amsterdam suburb, whose social horizons had progressively narrowed to a small radicalized circle, was part of a violent wider world connected by Internet, CD-ROMs, and MSN. (Buruma, 2006:17.)

The Dutch post-multi-culti confusion was part of a widespread phenomenon of people searching for their identity in a globalised world. In this context the quality and impact of the public debate was not effective. In 2006 Zwagerman delivered the "Kellendonk Lecture" at Nijmegen university and defended a literature in which societal issues are discussed. 7 Wondering why in Dutch literature there was no interest in topics such as 9/11, the murder of politician Pim For-

7 See Zwagerman (2006): "Tegen de literaire quarantaine". 
tuyn in 2002 and of Theo van Gogh in 2004, Zwagerman asserted that the Dutch view of literature is very much focused on "putting literature in quarantine", away from everyday life. Modern literature is locked up in an aesthetic domain, disconnected from what is happening in real life. However, writing literature does not mean that an author has to distribute pamphlets or develop a speakers' cornertype of political engagement. The author's writings do not have to contain an explicit ideological message, all he has to do is open the texts up to the current debates and issues.

Roeshoofd hemelt was published in 2005 and is an adequate literary response to the turbulence in Dutch society. The registers, repertoires and styles of language, the atmosphere of phony communication, hyper-sensitivity and lack of serious intellectual debate are well-articulated. By choosing the form of epic poetry, Zwagerman escaped both from the monologue of poetry and from the distinction of fiction. In the epic form he wrote a significant response to what was happening in the small corner of north-western Europe. He invented a character that was drowning in senseless speech and sought the explanation for the Dutch confusion in the unbearable lightness of consumerism.

\section{List of references}

BAL, M. 2002. Travelling concepts in the humanities: a rough guide. Toronto: University of Toronto Press.

BAUDRILLARD, J. 2007. The consumer society, myths \& structures. Repr. London: Sage.

BURUMA, I. 2006. Murder in Amsterdam: the death of Theo van Gogh and the limits of tolerance. New York: Penguin.

DUBROW, H. 2006. The interplay of narrative and lyric: competition, cooperation, and the case of the anticipatory amalgam. Narrative, 14(3):254270, Oct.

HERMANS, L. \& VERVAECK, B. 2007. Ideology. (In Herman, D., ed. The Cambridge companion to narrative. Cambridge: Cambridge University Press. p. 217-231.)

HEYNDERS, O. 2008. Politieke romans van vrouwelijke auteurs. Tijdschrift voor Nederlandse taal en letterkunde, 124:159-172.

JAHN, M. 2007. Focalization. (In Herman, D., ed. The Cambridge companion to narrative. Cambridge: Cambridge University Press. p. 94-109.)

PHELAN, J. 2007. Rhetoric/ethics. (In Herman, D., ed. The Cambridge companion to narrative. Cambridge: Cambridge University Press. p. 203-216.)

SCHEFFER, P. 2008. Het land van aankomst. Amsterdam: De Bezige Bij.

SONTAG, S. 2002. Illness as metaphor \& AIDS and its metaphors. London: Penguin.

ZWAGERMAN, J. 2005. Roeshoofd hemelt: gedichten. Amsterdam: De Arbeiderspers.

ZWAGERMAN, J. 2006. Transito. Amsterdam: De Arbeiderspers. 


\section{Key concepts:}

consumerism

cultural analysis

frame

manic-depressive illness

narrative poetry

voice

Kernbegrippe:

kulturele analise

maniese-depressiwiteit

narratiewe poësie

raam

stem

verbruikerskultuur 
